\title{
7. Domesticating the foreign: singing salvation through translation in the Australian Catholic Chinese community
}

\author{
Nicholas Ng
}

Audio samples and video footage relating to this chapter are available online at: http://epress.anu.edu.au/titles/sounds_translation_citation.html

\section{Introduction: singing of a different kind}

St Joseph's Chapel, Asiana Centre (Ashfield)

4 December 2004, 7.18pm

On the whole, this community is very well organised in what I see as a lively, post-Vatican II atmosphere...Hymns are sung in Cantonese and inculturation seems to have taken place at a moderate level: the Mandarin script is clearly visible in signs and religious slogans around the place...During the opening of the new Annex last year, there was a roast suckling pig that seemed to be an additional sacrifice to the usual one at Mass.

An ancestral plaque with a joss stick urn stands to one side of the old chapel. On All Souls' Day ${ }^{1}$ and Q ng Ming Jie, ${ }^{2}$ incense and joss sticks are lit with an offering of flowers and fruit. The ancestors are invoked...there is a Chinese saying: 'no ancestors, no identity'. ${ }^{3}$

And today, I attended the blessing of a statue of Our Lady of the Immaculate Conception...High on a Roman-style pillar, she stood pure and perfectly carved...[as] Father Tung sang the Tota Pulchra Est ('Thou Art Wholly Beautiful') in Latin in her honour.

Afterwards, in the community hall, the younger...generation murmured with calm reflect[ing] on what's cool and what's not in Sydney-slang. (From field notes, 2004)

On 4 December 2004, hundreds of Chinese Catholics congregated for mass in the burgeoning Sydney suburb of Ashfield. As voices rose in fervent song and praise with the incense and intoned prayers, it soon became apparent that this was no regular mass. Certainly, it was a feast on a grand scale that began with the procession of white-clad altar servers following a fraternity of friars, brothers and three concelebrant priests, one of whom was non-Chinese. Most probably 
for his convenience and that of the smattering of non-Chinese in the congregation, the entire liturgy was conducted in English while Cantonese and Mandarin translations of the psalms, scriptural readings, homily and community announcements were provided by laypeople speaking into a microphone at the lectern.

The music performed was of special note. At times, it was unaccompanied plainchant sung in answer and response between the main celebrant and the congregation. At other times, an electric organ accompanied 'traditional'-sounding Western hymns led by the choir. In addition were hymns more contemporary in sound accompanied by organ, amplified guitar, electric bass and drums. Cantonese and English were the languages used in song and not everyone referred to the hymnals provided; bilingual hymn texts and the proceedings of the mass in Chinese traditional script shone constantly from a data projector for those who needed them. After the final blessing, the altar servers and clergy genuflected and processed out to the lively strains of Give Thanks, a hymn in light rock-and-roll style written by liturgical lyricist and composer Henry Smith. The choir and congregation sang this single verse and refrain song of worship through in English once and repeated it in Cantonese. Energy was high and the eruption of conversation when the music ended was indicative of the cheerful mood shared by those present.

The people had gathered to celebrate the fiftieth year of their community's establishment. This event also launched the 'Wounded Church in China' project ${ }^{5}$ and commemorated the one hundred and fiftieth anniversary of the dogma of the Immaculate Conception of the Blessed Virgin Mary. In bright, celebratory colours, a picture of a highly stylised Asian Madonna and Child featured on the inside cover of a special souvenir edition of Marian Art published by The Catholic Weekly. As I stared with some wonderment at this icon, a number of questions sprang to mind: where, when and how did the intriguing corpus of music I had just heard come about? Why do these people continue to sing it? How do these people, known as the Australian Catholic Chinese Community (ACCC), maintain and preserve all three disparate identities (Australian, Catholic and Chinese) while asserting each one individually - or do they? Is it possible to be all three at the same time in what the media often portrays as the 'Chinese community' in general?

In this study, I attempt to address these questions through examining the contemporary musical performance practice of the ACCC. Through a unique music developed over more than 50 years, the community is able to assert on the one hand, its difference from other Catholics in Sydney, while on the other hand showing a willingness to adapt to its new surroundings. The community is also able to distinguish itself from other Chinese migrants in Sydney. What is often called the 'Chinese community' in Sydney is in fact a number of smaller 
migrant groups, each with similar values and common lifestyles. Music is closely linked to the cultural and social practices of these groups, bound either by religion, dialect and clanship or some form of common interest. The ACCC as a subgroup exhibits a unique culture in which the issue of translation is all important and has much to do with the current state of its music. ${ }^{6}$ While this music can be classified overall as 'hybrid', it is by the same token like one of the many 'flavours' of Chinese culture that exists in the globalised world.

This study posits that members of the ACCC form part of a transnational diasporic zone in which there exist continual links between 'the local and the global, the here and the there, past and present' (Ang 2001:34). Sydney's Chinese Catholics form what Mark Slobin (1993:64) dubs a 'diasporic interculture, which emerges from the linkages that subcultures set up across national boundaries'. By examining the music of this subculture, which is primarily a vocal genre, we can see how conscious decisions in musical style and composition, in addition to choice of language, are integral in helping people identify and adjust culturally to their new adopted homeland. On the one hand, the need to remain distinct from the majority of Australian society by preserving cultural elements is strong. On the other is an urge to translate what is considered foreign in the community into something more localised in order to adapt to the wider non-Chinese community. My analysis touches on the intersection of music, language and culture. Using field data gathered periodically from 2000 to 2004 and certain established theories combined with a general knowledge and understanding of the topic, this chapter shows how this sub-community of Chinese Catholics in Sydney creates a sacred space unique to themselves through the medium of song.

\section{Singing praise as one}

Music-making has been known to have the power to unite groups, strengthen cohesion among people within a community, and articulate ethnic identity. (Lau 2005:145)

Citing various scholars (see also Slobin 1994:245; Stokes 1994; Hosokawa 1998; Nettl 1983:162-5; Radano and Bohlman 2000:8; Averill 1994) in an article on Chinese amateur singing in Bangkok, Lau (2005:145) reminds us of the phenomenon in which music in the form of national anthems, songs of patriotism, military bands and national orchestras has often been used symbolically to create national and diasporic bonds. In the case of Sydney's Catholic Chinese, this musical adhesive functions to unite people in the worship of a single deity through poetic song texts describing aspects of their belief system. These texts, if not liturgically or scripturally related or inspired, can refer to some matter of religiosity and even instil a sense of nostalgia for an imagined homeland.

Hymn singing is not necessarily like the singing of national anthems, the words of which people have often 'remembered well enough to forget to understand' 
(Kelen 2003:162). Far from a phatic exercise, hymns and plainchant singing in one's native tongue communicates a sense of belonging and can be as strong a symbol of unity as it is a binding force in community groups worldwide. Hymns and plainchant sung during mass not only help reaffirm what people believe in, they help express a sense of collective identity as they sing to themselves and one another about what they hold dear to their hearts. Even in the most impersonal of church situations in which community members are acquainted on a superficial level limited to weekly contact, congregational singing still has the means to help people identify as a group. According to Frith (1996:121), song, or more precisely the act of responding to song, draws audiences into emotional alliances with performers. In the case of the ACCC, in the context of liturgical singing, I propose that the singing of sacred songs helps unify the group as one, in which social status, age, gender and other differences are forgotten in the music.

In his study of karaoke singing, Hiroshi Ogawa (1993) observes that the people present are enclosed within the walls of a 'karaoke space'. With everyone considered friends in this space, 'a person singing in the presence of others in spite of shyness is thought to be trusted. Both sharing a "karaoke space" and singing in the presence of others reinforce group consciousness' (Ogawa 1993:2). Although hymns are quite a different thing to karaoke, both preoccupations involve singing, and the same fundamentally human concept of 'group consciousness' applies. It is a consciousness in which many things are held in common and are essentially communicated. While any two people of any two societies can arguably be able to find things in common and locate a deferential point of identification, people who sing during mass identify at many levels because they are of the same community and are able to communicate the many things they hold in common. 'What they must have in common...are aims, beliefs, aspirations, knowledge - a common understanding - likemindedness as sociologists say' (Dewey 1916:5-6).

Casey Man Kong Lum (1996:21) believes that 'likemindedness among people gives them the identity of being members of a community. It is this likemindedness among people that forms their common frame of reference to construct and comprehend their social and cultural reality.' For Catholic Chinese in Sydney, this reality is one of belonging to a religion as an ethnic group in a multicultural nation in which their ethnicity separates them from society as 'different'. They possess a common belief system and culture easily communicated through the music of their community. Furthermore, Christopher Small (1998:9) maintains that the making of music is a convenient channel through which an individual or groups of individuals express or cultivate their identity in relation to their social environment. For Chinese Catholics, apart from using hymns as an expression of faith, singing sacred music is a powerful and evocative way to assert a sense of Chinese-ness in community groups in the homeland and in new 
areas of settlement within the diaspora. Undoubtedly, hymns and plainchant sung in one's native tongue are rich in religious and ethnic meaning. Although it is not possible for me to write on a general basis for all Chinese Catholic communities worldwide, it is quite certain that the religious culture of these groups is subject to change with the onset of migration. This will be shown in the following discussion using the case study of the ACCC in Sydney.

\section{Singing praise from the home front and beyond}

The families and religious workers who established the beginnings of the ACCC in Sydney originated mostly from the southern Chinese province of Guangdong and what is now the Hong Kong Semi-Autonomous Region. Audrey Donnithorne (Personal communication, 10 May 2006, 13 May 2006) remembers that these émigrés came from a practice of sacred music that involved plainchant in Latin (synonymous with Chinese Catholic worship for many centuries) and hymn singing taken from plainchant and other genres (a more recent practice introduced by missionaries from the 1800s). Catholic hymnody today is unlike that of the Latin hymns of the past. ${ }^{7}$ The present-day hymnody was developed to counter the Protestant hymn movement. Until the Second Vatican Council (1962-65), all sacramental celebrations including the Holy Mass were conducted in Latin, according to Father Bonaventure Tung (2006). With the reforms of Vatican II, during which 'inculturation' ${ }^{8}$ was encouraged, the devout in Guangdong and Hong Kong started to worship and sing in Cantonese while Latin fell into disuse. In the colonial climate of Hong Kong, spoken and sung English were also introduced to worship. By the 1970s, Chinese locals had domesticated and made 'native' the monotheistic religious culture from Europe that they had embraced in the search for salvation. Their foreign Roman God was now made local and many Chinese soon found Catholicism closer to home with the liturgy and other sacred texts translated into their native tongue. Not all condoned the changes made. To the dismay of many traditionalists, classical hymn texts in archaic Chinese verse were rewritten in everyday language while tangible expressions of religious culture such as statues, holy picture cards and other ecclesiastical paraphernalia ${ }^{9}$ were increasingly Sinicised. Throughout China, Hong Kong and Taiwan, local dialects and languages were employed to unite the people in song during worship by translating Western hymns and even Western folk songs with religious texts into the vernacular, and by the composition of contemporary hymns.

Such was the unifying socio-religious practice that was brought to Sydney from 1954 with the invitation of Sir Norman Thomas Cardinal Gilroy (then Archbishop of Sydney) for Father Pascal Chang and the late Bishop Leonard Hsu to launch the Sydney Catholic Chinese Mission. ${ }^{10}$ In 1989, the umbrella organisation of the ACCC was officially formed as a board of trustees and as a central and organising entity for its three primary branches (Table 7.1). 
Table 7.1 Australian Catholic Chinese community branch structure (1989)

\begin{tabular}{|l|l|l|l|l|l|}
\hline Branch & Established & Location & Choir & $\begin{array}{l}\text { Main } \\
\text { language }\end{array}$ & $\begin{array}{l}\text { Countries } \\
\text { of origin }\end{array}$ \\
\hline $\begin{array}{l}\text { Catholic } \\
\text { Chinese } \\
\text { Pastoral } \\
\text { Centre } \\
\text { (CCPC) }\end{array}$ & $\begin{array}{l}1954 \\
\text { moved to } \\
\text { present } \\
\text { location in } \\
1985)\end{array}$ & $\begin{array}{l}\text { Crypt of St } \\
\text { Mary's } \\
\text { Cathedral St } \\
\text { Peter } \\
\text { Julian's } \\
\text { Church, } \\
\text { Chinatown }\end{array}$ & CCPC choir & Cantonese & Hong Kong \\
\hline $\begin{array}{l}\text { Asiana } \\
\text { Centre } \\
\text { Association } \\
\text { (ACA) }\end{array}$ & 1973 & $\begin{array}{l}\text { Asiana } \\
\text { Centre, } \\
\text { Ashfield }\end{array}$ & CCPC choir & Cantonese & Hong Kong \\
\hline $\begin{array}{l}\text { Western } \\
\text { Sydney } \\
\text { Catholic } \\
\text { Chinese } \\
\begin{array}{l}\text { Community } \\
\text { (WSCCC) }\end{array}\end{array}$ & 1990 & $\begin{array}{l}\text { St Dominic's } \\
\text { Church, } \\
\text { Flemington }\end{array}$ & $\begin{array}{l}\text { WSCCC } \\
\text { choir }\end{array}$ & Mandarin & $\begin{array}{l}\text { Taiwan, } \\
\text { Laos, } \\
\text { Cambodia, } \\
\text { Vietnam, } \\
\text { Singapore, } \\
\text { Malaysia } \\
\text { and } \\
\text { Timor-Leste }\end{array}$ \\
\hline
\end{tabular}

Source: Summarised from <http://www.chinese.sydney.catholic.org.au/E_Accc.htm> (viewed 7 May 2005).

\section{CCPC, ACA and WSCCC}

Under the pastoral care of Father Bonaventure Tung, the current Chinese migrant chaplain, the three branches of the ACCC combine to provide welfare and ecumenical services in addition to community activities for Chinese Catholics in Sydney who choose to meet, sing and worship with others of the same ethnic and religious orientation. ${ }^{11}$ As recorded in Figure 7.1, the Catholic Chinese Pastoral Centre (CCPC) and Asiana Centre Association (ACA) in the city and eastern suburbs form a meeting ground for what is essentially a Cantonese congregation of expatriate Hong Kong Catholics and their descendents. Further west at St Dominic's, the Western Sydney Catholic Chinese Community (WSCCC) is a highly multinational community that has coalesced as a huawen (Mandarin-language) unit due to the plethora of mother tongues spoken at home. These Catholics meet under the spiritual directorship of Father Paul McGee from the Columban Mission Institute. In general, the culture of the most populous Chinese subgroup tends to prevail over the wider community. Hence, because Hong Kong migrants are greater in number than Mandarin speakers from Taiwan and wider Asia, Hong Kong culture appears strong in the ACCC at large. Meanwhile, Taiwanese music, food and general presentation tend to dominate 
the Mandarin-speaking congregation (WSCCC). Language barriers and subcultural marginalisation are, however, seen as minor issues because community members in their respective chosen subgroups are happily able to sing, worship, communicate and read in the vernacular, which in traditional script can be read in either Cantonese or Mandarin. Children are sent to Sunday school and many attend the Asiana Centre Catholic Chinese School where Cantonese or Mandarin are taught.

\section{Figure 7.1 Sydney Chinese Catholic Mission pamphlet}
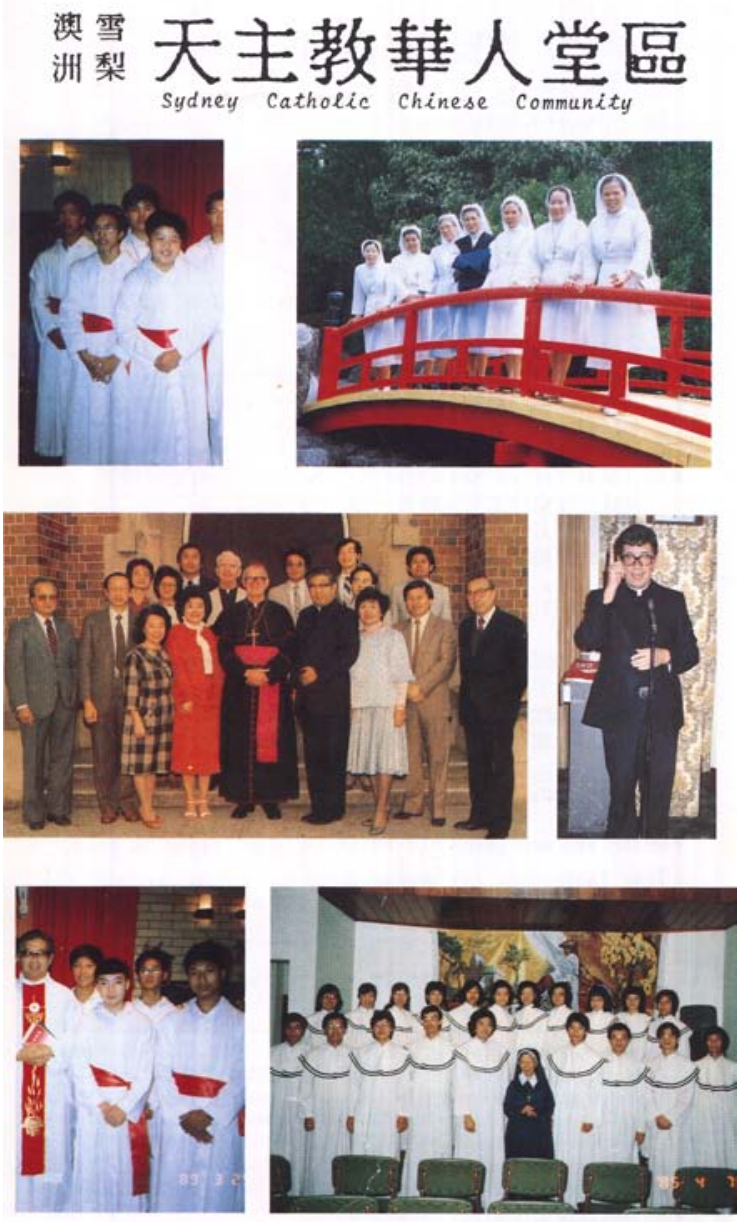

雪梨天主教華人牧要辦事虎

Sydney Catholic Chinese Pastoral office

432 Sussex St., Haymarket 2080 Phone: (02) 212-6823 
The Sydney Catholic Chinese community is essentially a support group for migrants, which many of their children are not. Father McGee (Interviews, 4 October 2000, 15 October 2000; Phone communication, 7 April 2004), who administers the Mandarin congregation in the western suburbs of Sydney, observes that most migrant children go to school and receive a tertiary education, then leave the community when they find a job. An example of this is the Chungyue children at St Dominic's. Adelino and Iana Chungyue (Interview, 3 September 2000), a Chinese couple from Timor-Leste, say their children used to play the violin and organ at mass but now have found full-time work and are consequently 'too busy'. There are many similar cases to this happening today. The community is, however, still flourishing, with young children to university-level people currently living under their parents' influence. English speaking and bicultural, they could be there 'because Dad will kill me' otherwise, but for the present, they are building close bonds established with peers from an early age. Many, especially the children of community executive board members, are altar servers (male and female) and acolytes and participate in activities such as camps at St Francisville (the community's place of retreat) and other church-related interest and religious groups such as the St Louis Group. There have even been evangelical groups of young people who take to the streets to 'spread the Good News' to Chinese and non-Chinese with information pamphlets about the ACCC. Some even take pride in their 'Chinese-ness' and stay with the community for that very reason. 'We all grow up with something but we can choose anything by way of expressive culture' (Slobin 1993:55).

In the very way described by Slobin in the quote above, community members I have worked with certainly choose to live Catholic lives among people of the same ethnic origin. Together, they sing, eat and speak 'Chinese' in their worship of Christ. Instead of going to mainstream English mass, some community members travel long distances to Chinese Catholic centres in Sydney for religious and cultural purposes. When asked why they prefer meeting and worshipping with other Chinese, the general response from community members is that the familiarity of it all makes them 'feel comfortable'. Further comfort comes from singing and speaking in a Chinese tongue. This enables participants to identify as Chinese. Clearly, many Catholic Chinese, especially recent and elderly migrants, are affected by having to adjust to their new surroundings. The remedy to this sense of displacement is quick and easy: finding solace in the church community, which apart from offering spiritual nourishment provides them with social and mental relief from the (quite possibly externally and internally imposed) stigma of being foreign simply by being with other people who are equally foreign. In mainstream Australia, Chinese Catholics cannot help but find that they and their culture are starkly different from other Catholics and, to a certain extent, other Chinese. Catholicism existed in Sydney before their arrival, but theirs is a unique Chinese Catholic culture of a different hue, and of a different temperament that 
appears very foreign despite its highly domesticated and localised nature in the homeland. Their language, their Sinicised paraphernalia and their music are all attributes of difference that mark them as distinct from other non-Chinese Catholics in Sydney. To this day, members of the Catholic Chinese community in Sydney practice with great fervour a European religious way of life imbued with native Chinese elements, which in the old country was the result of years of adaptation into the local Chinese culture. It certainly is a vibrant, post-Vatican II atmosphere that exists today.

\section{Figure 7.2 Suckling pig}

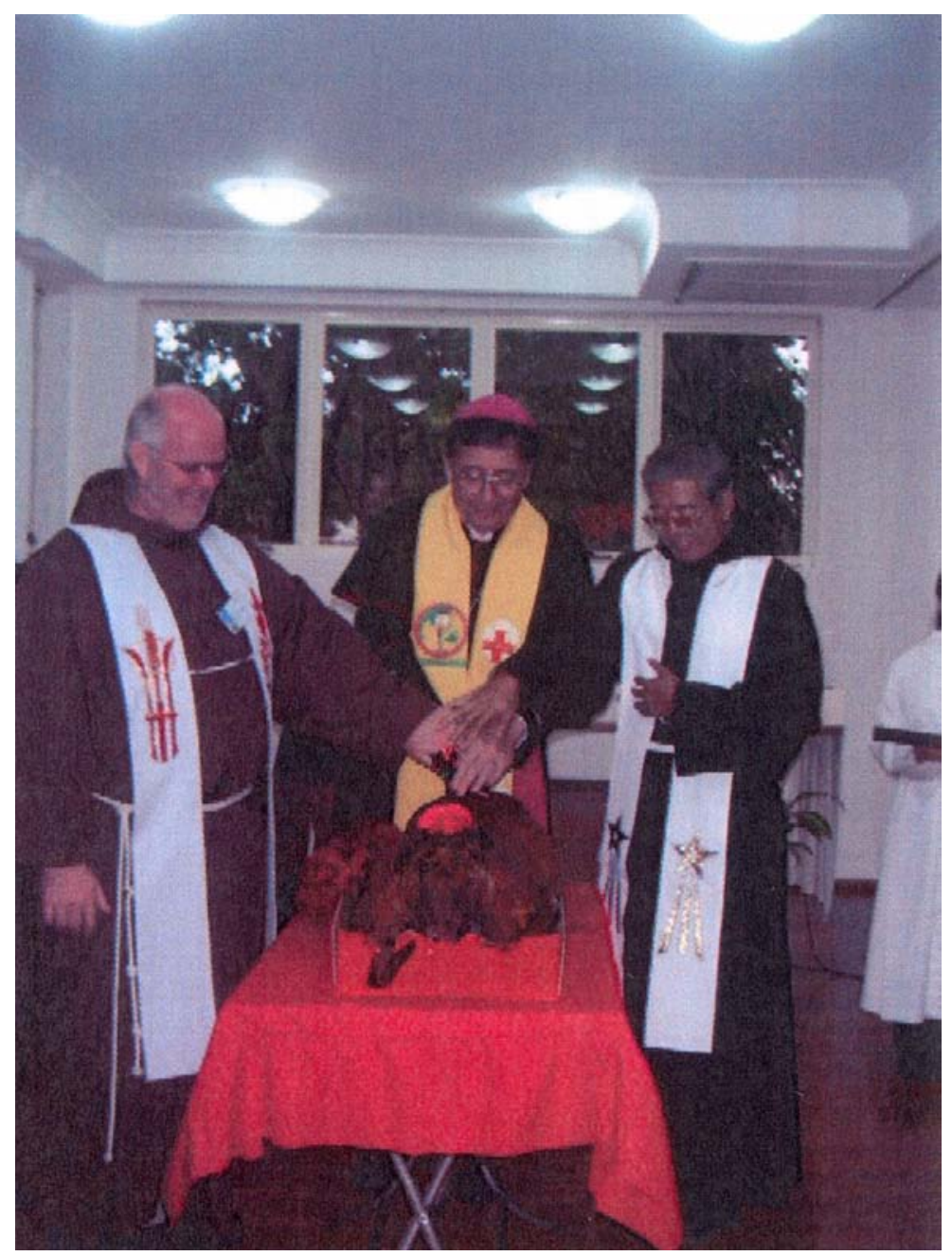


Figure 7.3 Ancestral altar

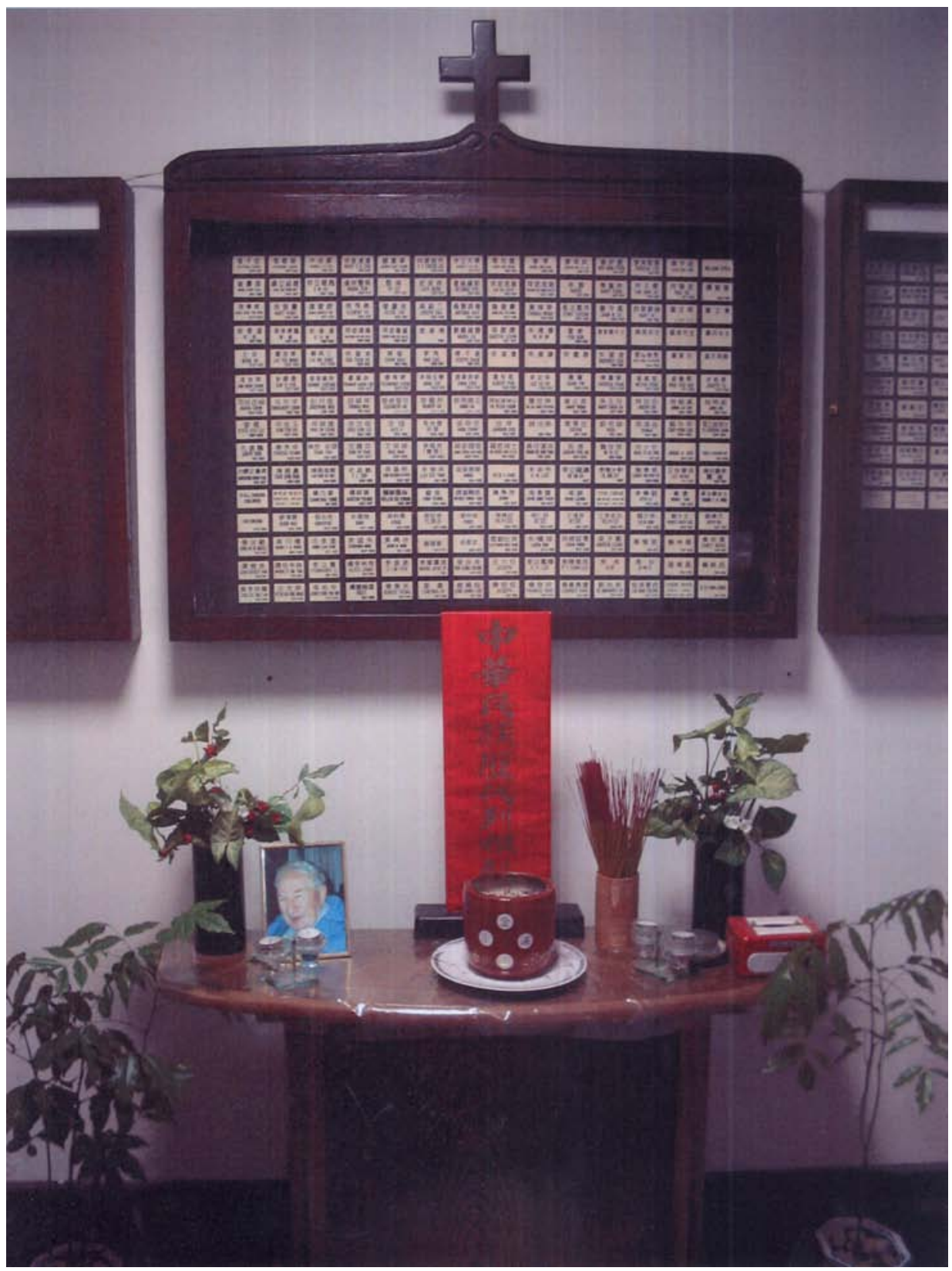




\section{Figure 7.4 Father Tung with Our Lady of the Immaculate Conception}

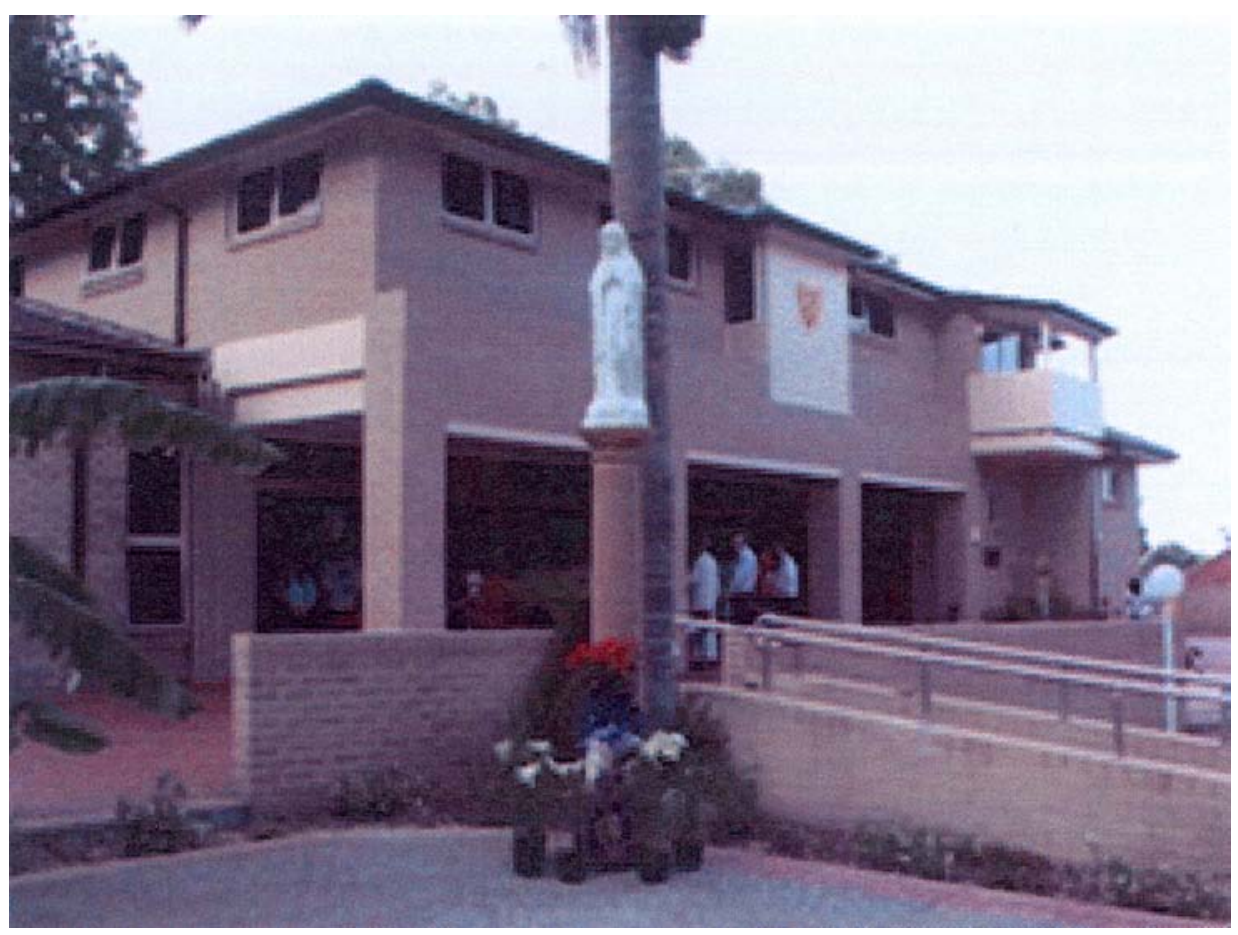

"Chineseness" is not an immutable set of beliefs and practices, but a process which captures a wide range of emotions and states of being' (Siu 1993:19). Edith Lo, who has been a choir member in the Cantonese-speaking congregation since 1985, believes it is important to exhibit her community's Chinese-ness at large events that are exposed to the public eye. Chinese New Year mass is one example. Each New Year, an ancient Chinese rite for the veneration of ancestors is practised. This ritual has been reintroduced into Chinese Catholic communities worldwide after several centuries of debate in the Vatican, which initially barred the practice (Interview with Edith Lo, 10 September 2000). Taking part in such rituals today allows the Chinese to celebrate an ethnicity that is different to the mainstream; it is something the Chinese Catholics in Sydney do with a certain pride. The picture of the Chinese Madonna and Child mentioned at the start of this chapter was vastly unlike any of the European presentations of the Virgin in the special souvenir edition of Marian Art published by The Catholic Weekly. Beneath the picture were the words 'Dedicated to Our Lady by the Australian Catholic Chinese Community to commemorate the celebration'. 


\section{Figure 7.5 Chinese Madonna and Child}

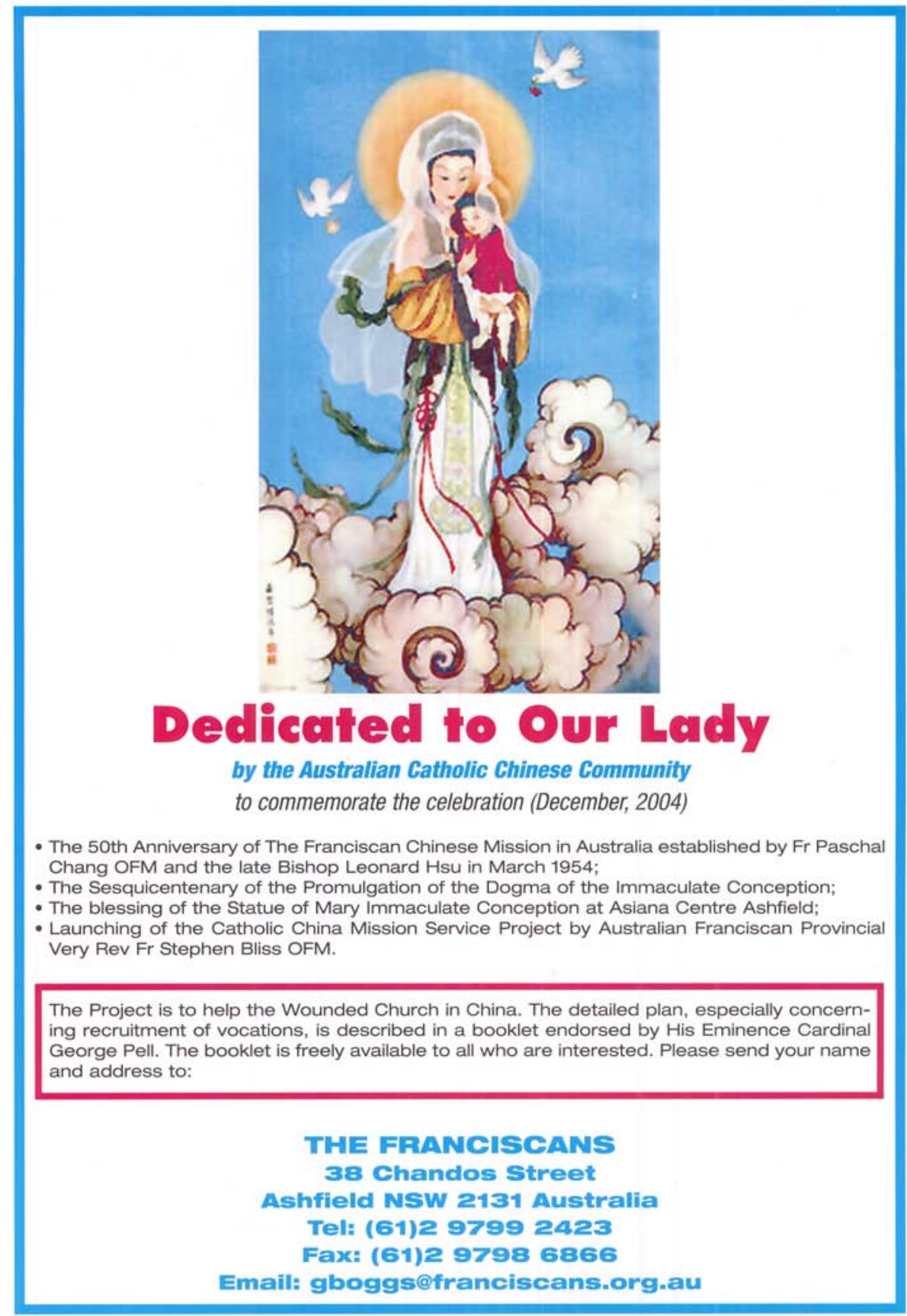


In such representations from the media, there is no shame in appearing as a distinctly different group with a different history, of which 50 years on Australian soil is worth celebrating. At the community's golden anniversary, as with other large events to which important outsiders are invited, 'Chinese-ness' is exhibited in language, native customs and music through the medium of the mass. The use of English in hymns and parts of the liturgy, however, ensures that visitors from the outside are not entirely alienated from the proceedings. Hence, it is not simply a Chinese Catholic culture that is exhibited but a new, modified one in which we can observe the preservation of the old homeland culture and their attempts to adjust, reach out and relate to the wider Australian community as Australian Chinese. This can be seen most clearly in the sacred songs they sing today and their approach to language use.

\section{Singing praise in the new homeland}

The hymnals used by the ACCC were published in the 1980s after the wave of Sinicisation and inculturation of the 1960s and 1970s. The CCPC choir (established in 1985; see Figure 7.6) and the WSCCC choir (established c1998-99) thus lead their respective congregations in song during mass from hymnals that facilitate the preservation of pre-existing musical traditions. There are two main hymnals in current use: one from Hong Kong and another from Taiwan. World-renowned liturgist and composer Father Lucien Deiss played an immensely influential part in the development of the Catholic Chinese hymnody. Cantonese-speaking ACA and CCPC members sing from the Hong Kong-published hymnal, which exists in two volumes. This hymnal employs a combination of Western and cipher music notation ${ }^{12}$ in the Pew Edition (see Music 7.1), while the Organ Edition is entirely in Western staff notation (see Music 7.2). Meanwhile, the WSCCC sings from a Taiwan-published Mandarin hymnal in cipher notation only, with guitar chords stipulated above the easy-to-learn melodies (see Music 7.3). ${ }^{13}$ Following are three excerpts taken from religious services from all three branches of the wider ACCC that are very much in the 'old' tradition of music for worship. Traditionally performed in the Western world, these musical items have been translated into Mandarin and Cantonese for use during mass and other Roman Catholic rites in the community. 


\section{Music 7.1 Huáng Huáng Shèng Ti}
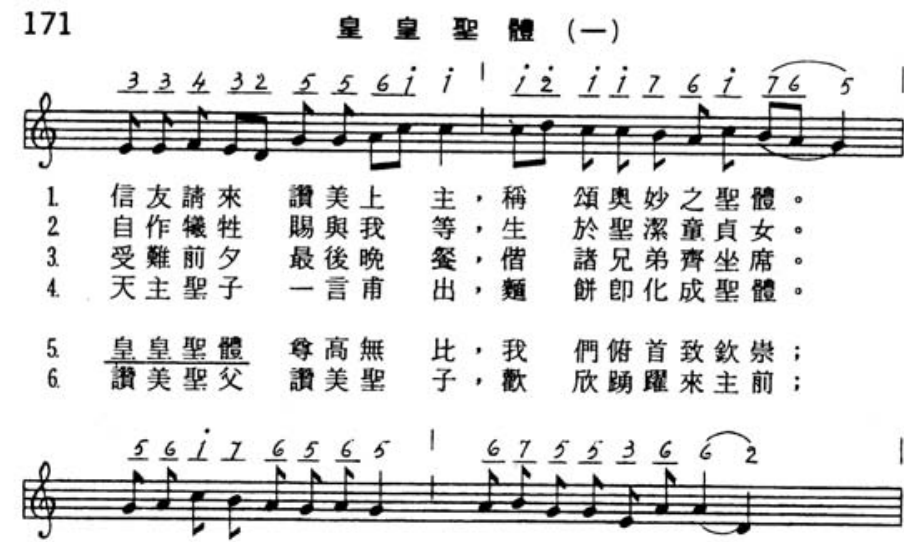

1 又請稱頌至聖留血, 主因䞆世缜傾流。

2 在世居住要情昭著, 福音廣佈苦不辟。

3. 徽底莩守古教規禮, 巴斯卦節食羔羊。

4. 苩萄酒亦成象聖血, 此中奥妙洞悉雉。

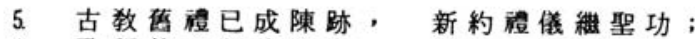

6 . 歌㥧救主凱旋癷利, 圙揚主德浩無邉;

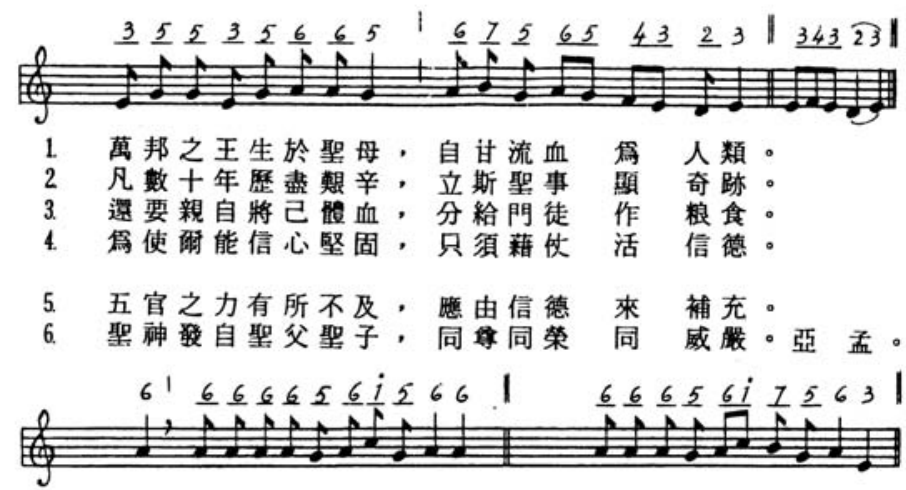

（司）主, 你賜給我們天國的食桹・（寀）它給我們帶 來了喜樂。

詿衆同禅：主, 你在追奇妙的聖事內, 留給了我們受難的紀念; 求你帮助我們度誠欽崇你唱血的神聖奥跡, 俺能常常 領受你救頑的功效。你永生永王。

衆：亞孟。 
1 Sing, my tongue, the - Saviour's glory, of- his Flesh the mystery sing: Of the Blood, all price exceeding, Shed by our immortal King,

Destined, for the world's redemption, From a noble-womb-to spring.

2 Of a pure and-spotless Virgin, Bom-for us on earth below,

$\mathrm{He}$, as man, with man conversing, Stayed, the seeds of truth to sow;

Then he closed in solemn order, Wondrously his-life-of woe.

3 On the night of-that Lost Supper, Seated with his chosen band,

$\mathrm{He}$, the Paschal victim eating, First fulfils the Law's command;

Then as food to his apostles, Gives himself with-his-own hand.

4 Word made flesh, the-bread of naturer Bythis word to flesh he tums; Wine into his blood he changes: What though sense no change discems? Only be the heart in eamest, Faith her lesson quickly leams.

\section{TANTUM ERGO}

5 Come, adore this-wondrous Presencel Bow-to Christ, the source of grace! Here is kept the ancient promise, Of God's earthly dwelling-placel

Sight is blind before God's glory, Faith alone may-see-his facel

6 Glory be to-God the Father! Praise-to his coequal Sonl Adoration to the Spirit, Bond of love, in Godhead one. Blest be God by all creation, Joyously while-ages runl Amen.

V. You have given your people bread from heoven. (Alleluia)

R. The bread which is full of all goodness. (Allolvia) 
Sounds in Translation

\section{Music 7.2 Fāng Jì Gé Dè Qí Dao}
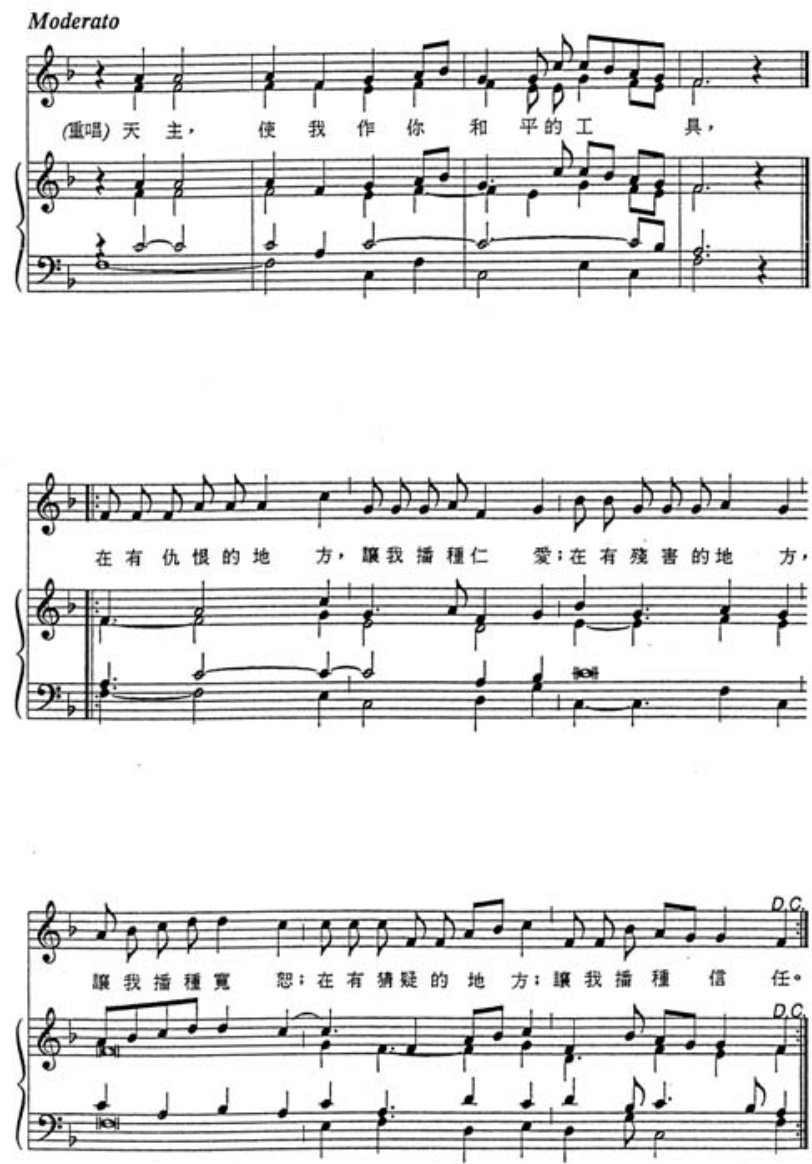

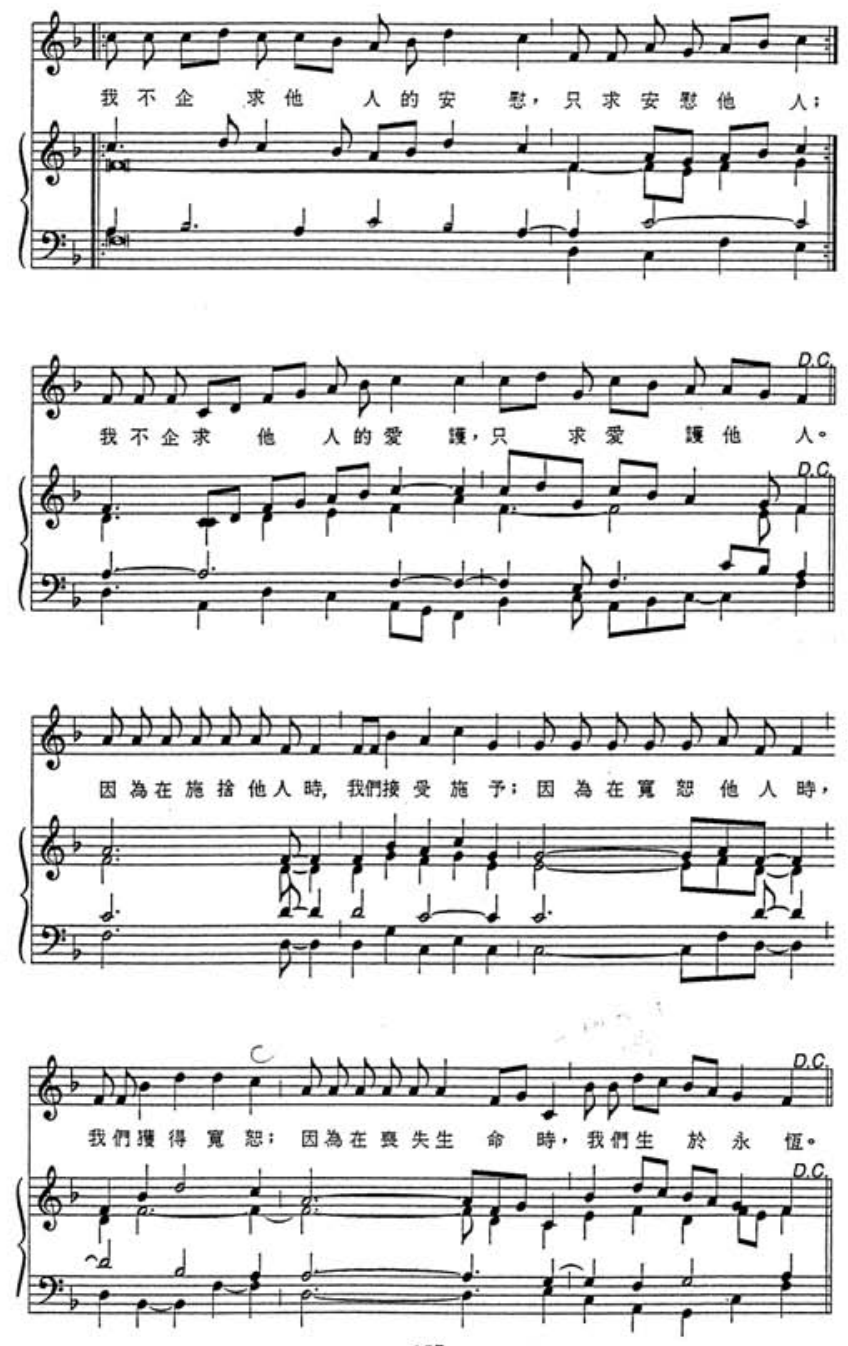

157 


\section{Music 7.3 Gāo Yáng Zhàn}

F $4 / 4$

\section{羔羊 讚(-)}

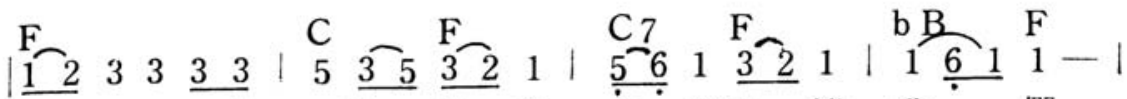

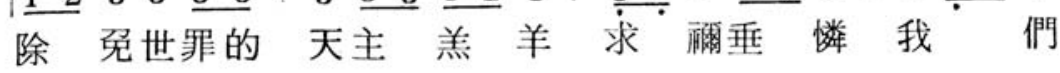

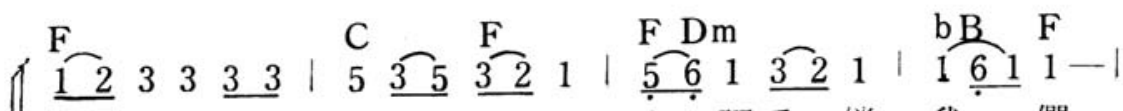
除免世罪的 天主羔羊求禰垂憐 我們

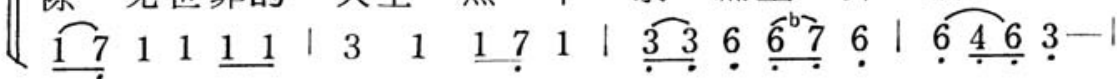

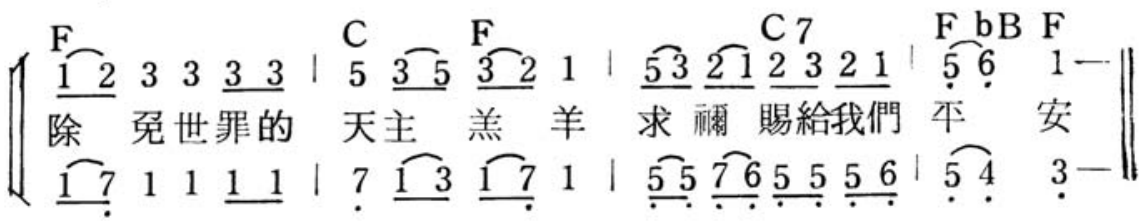

Figure 7.6 The CCPC choir

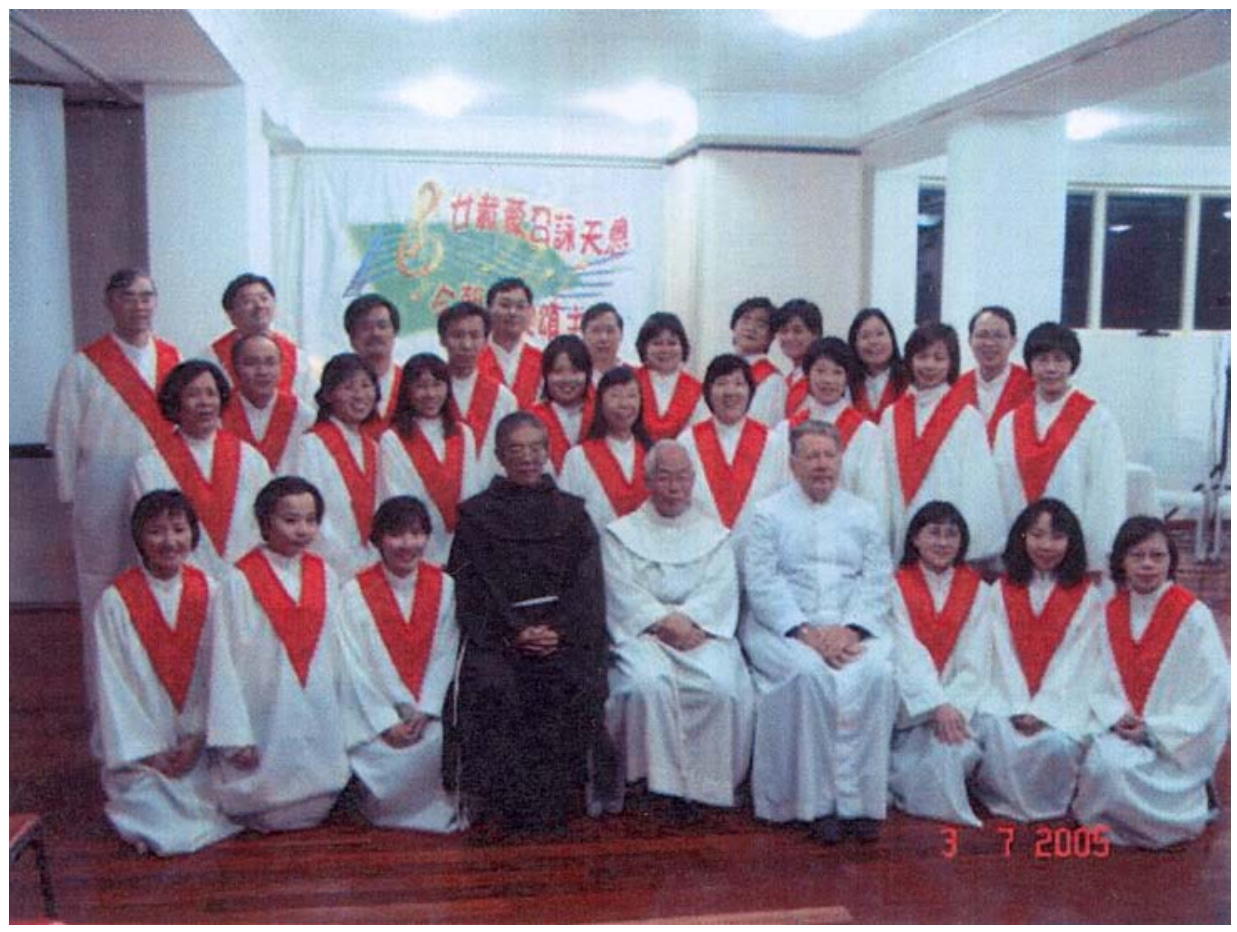


The Doxology of Praise 'Through Him, with Him, in Him' (see Video 7.1) was intoned by Father Tung to conclude the Eucharistic Prayer during Easter Sunday mass in 2003. It was faithful to the original plainchant tune but sung in Mandarin. There are different points of reference, association and meaning here. The priest was singing in Mandarin, which he used in Cantonese and Mandarin communities. The Cantonese group might find this still slightly foreign and could only try localising this foreignness by having translators during mass. For them, God is still someone they cannot quite understand for neither of the Chinese pastors (Father Tung and Father Chang) speaks any Cantonese. At the twentieth anniversary of the Cantonese choir's establishment in July 2005, a play written by community members was enacted in which the people heard the voice of God, which was in fact the recording of Father Chang's voice in Mandarin.

The Pange Lingua Gloriosi is another example of plainchant (see Video 7.2). More specifically, it is a plainchant hymn, the melody of which is supported in this instance by basic diatonic chords (primarily I, IV and V). During a Saturday-night novena, the ACA and CCPC congregations sang in Cantonese in adoration of the Blessed Sacrament (see Audio 7.1). According to living memory, Pange Lingua Gloriosi was sung in the vernacular even before the reforms of the Second Vatican Council in the 1960s. This Latin hymn is one of the oldest in Catholicism and can be traced to the Middle Ages; its text was composed by the great St Thomas Aquinas (1225-74) for the Solemnity of Corpus Christi. It is considered one of the seven-greatest hymns of the Church (Martin 1998). In contrast, the Doxology of Praise would have been in Latin until the changes encouraged by Vatican II took place, as it was part of the liturgy. Plainchant, accompanied and unaccompanied, is an example of sacred music performed in the Chinese community of Sydney.

$P$ Shì Tóng $H$ an Chàng is a traditional hymn many in Christendom know as Thine Be the Glory from Handel's oratorio Judas Maccabaeus (see Video 7.3). In this Chinese rendition, the original melody and organ accompaniment have been retained with text in Mandarin on the glories of the risen Christ. $P$ Shi Tóng $H$ an Chàng is an example of the many hymns in Taiwanese and Cantonese hymnals that are essentially translations of hymns from the corpus of Catholic hymnody developed in the 1800s and early 1900s.

The musical items in Videos 7.1, 7.2 and 7.3 reflect what can be seen as an initial step towards the development of Chinese Catholic music with translation alone as the main focus. At this early stage, there is not much in the way of inculturation or assertion of a Chinese identity apart from language use. In contrast with the above are hymns that depart from what we might call the 'traditional' and 'conventional' in Roman Catholic congregational singing (the development of which has been influenced largely by Protestant hymns) to 
musical items that are more localised and innovative, a move fostered worldwide by Vatican II.

During Easter Sunday mass, the congregation of the WSCCC sings (in Mandarin) 'Lamb of God, You have taken away the sin of the world, have mercy on us' to the accompaniment of the electric organ (Video 7.4 and Audio 7.3). From my analysis of the ACA/CCPC and WSCCC hymnals, this is an interesting example of Catholic Chinese music developed in the 1970s that is still very much in vogue today. The text is set to a melody based entirely on a pentatonic scale often associated with 'Chinese music' (D, E, F\#, A, B). According to community members, this gives it a 'Chinese sound'. Chinese music is generally not chorded but operates on the principal of heterophony. In this particular hymn, however, the composer has supported the melody with chordal accompaniment borrowed from Western music, the chief characteristics of which are widely acknowledged as harmony and counterpoint. According to my informants, weaving Chinese melodies over diatonic Western chords was a way of integrating a sense of native Chinese identity with the foreign musical culture of their religion. Looking through the community's hymnals, I found this to be the case for many twentieth-century Chinese hymns. Today, the efforts of inculturation in the 1970s seem to have paid off: items such as Gāo Yáng Zhàn are still sung in the Sydney community. There are also more hymns being composed in this fashion. Edith Lo (Interview, 10 September 2000), former president of the CCPC choir, says that hymns today are increasingly Chinese sounding with the use of 'Chinese tunes'. I am assuming that she also means hymns composed in a way similar to Gāo Yáng Zhàn - that is, supported by diatonic chords. In Gāo Yáng Zhàn, the selection of chords is the tonic, subdominant and dominant - what trained musicians might regard a simple selection of chords, no doubt, but this is for a good purpose: members of the community tell me the hymns in their community are designed for easy learning and convenience.

When writing Chinese hymns, it is important to take into consideration not so much metre but the tonal nature of the language or dialect concerned. Eddie and Annie Ho (Interview, 31 July 2005), two longstanding members of the CCPC choir, assert that writing Cantonese hymns is no simple exercise due to the dialect's nine tones as opposed to the four of standard Mandarin. ${ }^{14}$ As a result, simply singing Western hymns translated into Cantonese, or indeed translated from any language or dialect, often leads to confusion. An embarrassing situation involves the Cantonese word 'jyu3' ('God') (Audio 7.1) sung on the high note of 'jyul' ('pig') (Audio 7.2). For this reason, modern compositions by native Cantonese composers are highly valued in the old country and in Sydney as well, in the continuing interest of composing hymns in Chinese. In the homeland, it is part of the domesticating mission fuelled by Vatican II; in Sydney, it helps assert a Chinese identity and is what helps define cultural and ethnic boundaries between their community, mainstream Catholics and others. 
An example of a local Sydney product using Cantonese is a composition by Eddie Ho (Music 7.4). It was written for the Hé Ho ('Reconciliation') 2000 project from which many compositions in English and Cantonese emerged, in addition to the production of a CD, Aì G Rén Sh ng Lù (Music Lovers' Life Journey) (Figure 7.7 and Audio 7.3). Ho's composition was the winning piece in the liturgical music competition that was run that year. He is conscious that it is a 'Western' composition, which, according to him and his wife, was 'inspired by the Holy Spirit' and completed mostly in the shower over several weeks. A fan of evangelical, processional/recessional-type hymns, Ho designed it to be easily learnt for it was essentially a 'children's marching song'.

With its triadic harmony and step-wise melody, this hymn is, as Ho describes, Western in every respect, with the exception of the Chinese text, which is in contemporary (though formal) Cantonese. This hymn can also be sung in English and exists in both versions on the CD Aì G Rén Sh ng Lù. The single verse celebrates the intervention of Jesus in our lives of the past, present and future. It is partially related to the liturgy: the first part of the chorus is based on the Doxology of Praise from the Eucharistic Prayer while the remaining words call on Christians 'to brave the world and march forward under the grace of the Triune God' (Interviews with Eddie Ho, 8 December 2005, 14 December 2005). ${ }^{15}$ Compositions such as Ho's are well regarded in the Sydney community not least because the melodic contour suits the Cantonese language perfectly without any need for altering the original text when transliterated from Mandarin, or translating it from a foreign language - a constant problem for the choir. Eddie and Annie believe that much of the beauty in singing sacred Chinese texts translated from European languages is 'lost in translation'. In Annie's opinion, the English language is not nearly as expressive as Cantonese or Mandarin, which in poetic form are elegant in their diminutive, metric nature (Interview with Annie Ho, 2005).

Eddie's piece very much complies with the Second Vatican Council's mission to indigenise the Catholic faith worldwide. Although it was composed in Sydney, this composition could be included with the preceding excerpts that exemplified the sacred music developed by the Chinese on home territory in localising their faith from a foreign belief system to one more domesticated. As mentioned earlier, this localisation was achieved through certain choices made in language, musical style and the writing of new compositions. With migration to Sydney where, to borrow Anderson's (1991) terms, 'host country' gradually turned into the 'new homeland', language and style once again became issues of consideration in the production of music. For a migrant group on alien ground, it had become evident that what was once native in the home country had reverted back to being foreign, or at least could be seen as foreign in light of the Anglo-Celtic mainstream culture. 


\section{Music 7.4 Yéh Sū Yíng Dăo Gùo Chì}
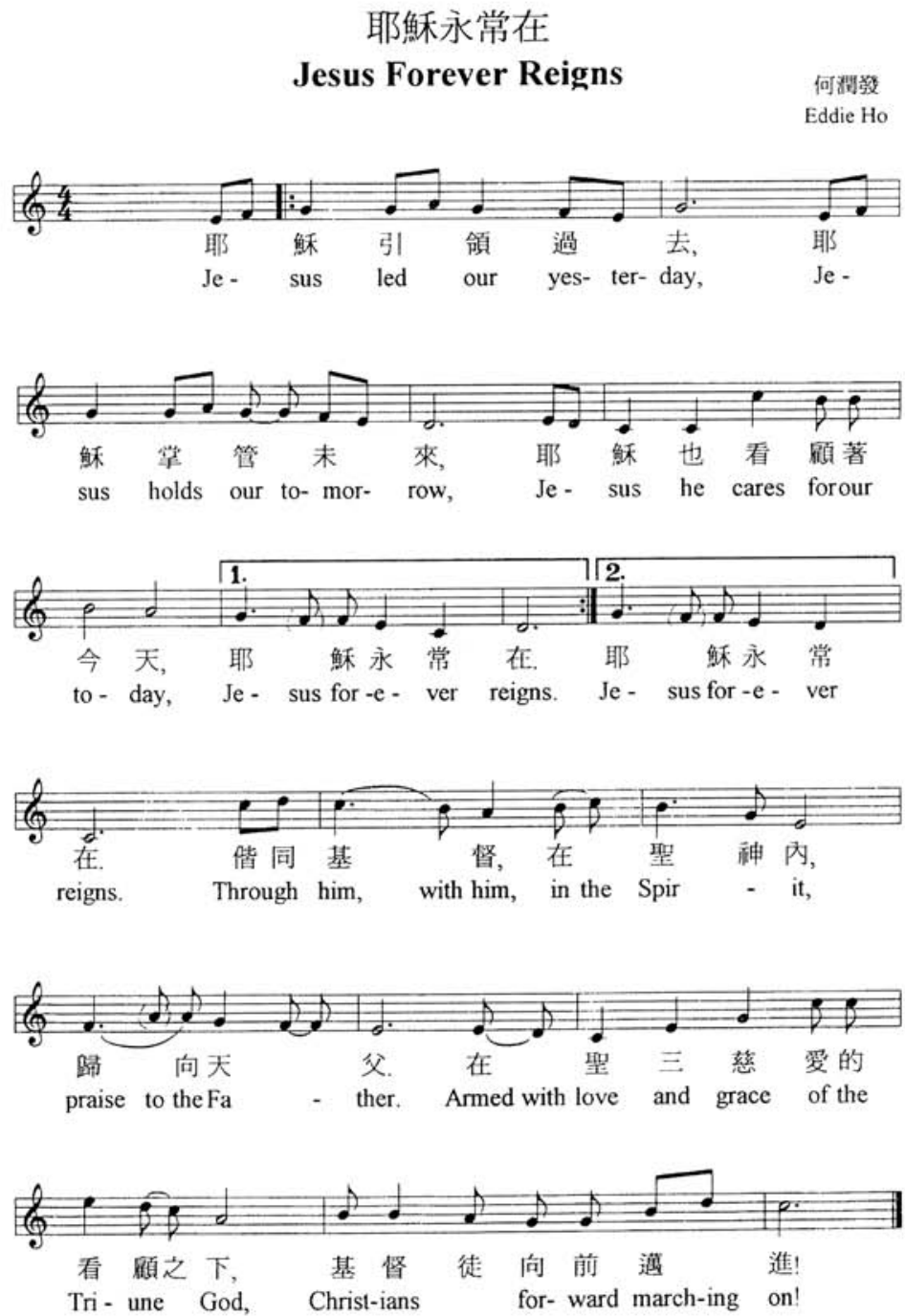
Figure 7.7 Aì Gē Rén Shēng Lù

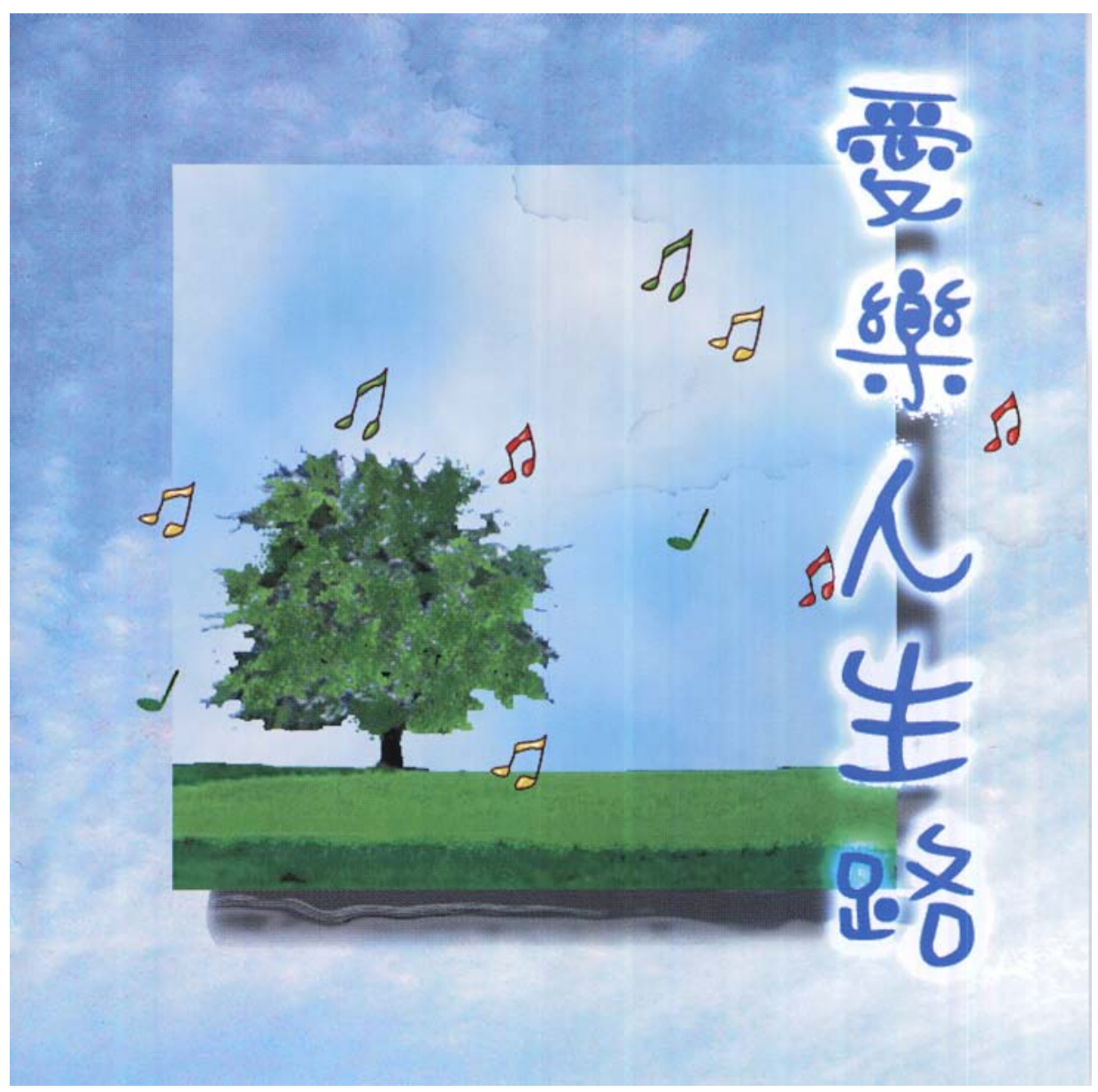


Hymns such as Yéh S Ying Do Gùo Chì, written for the community's Aì G Rén Sh ng $L \grave{u} \mathrm{CD}$, can be seen as a reaction to this sense of foreignness in its superimposition of Western music (in melody and harmony) in a bilingual setting (Cantonese and English). On the one hand, it is perfectly suited to being sung in Cantonese, making it exclusively a composition for the composer's immediate Cantonese-speaking community of the ACA and CCPC. The hymn can be considered a representative item for the community, hence assisting it (like the Chinese Madonna and Child) in appearing different from the mainstream. On the other hand, the situation seems remarkably inverted when sung in English, because it can then almost be considered a local product of a community fully assimilated and adapted to its local English-speaking surroundings. Hence, Eddie's composition is able to translate group identity in setting up a barrier of difference as well as in helping the community assimilate and cater to their predominantly English-speaking children.

Chinese communities across the globe have for centuries learned to adapt, accommodate and assimilate wherever they go with the establishment of a strong economic base and a community centre (Heilbron 1998:xiv). The migrants who make up the Sydney Catholic Chinese community are no different. According to one informant, there is always in the migration process an old Chinese mode of conduct or 'etiquette' at work, the origins of which can be found in Confucianism and which comes close to the English 'when in Rome, do as the Romans do'. In the view of this informant and many others, it is important to respect and learn the ways of the locals you live among without forgetting to retain one's own language, for, as Victoria $\mathrm{Ng}$ believes, it is largely through language that culture is preserved (Interview with Victoria Ng, 27 May 2005). Community members in the vast ethnic arena of suburban Sydney have started to live lives of 'multiple identities' in the effort to adapt to the new culture and preserve the old with 'ongoing and regular interaction between local cultures' (Chun 1996:96).

For Chinese Catholics who live as a pocketed community in mainstream Sydney society, interaction with non-Chinese means locating ways for adapting and relating to the wider community. Bringing in English and music used in mainstream English mass was the principle means to this end. During the community's fiftieth anniversary mass in Sydney, I sang along in English to a well-known Australian mass setting by Brother Colin Smith and the 'Our Father'. According to Zita Ho (Interviews, 30 November 2004, 3 December 2004, 29 June 2005, 31 July 2005, 6 December 2005, 9 December 2005 and 12 December 2005), the use of the English language and Australian content served the specific purpose of accommodating the non-Chinese chief celebrant and visitors there. Having non-Chinese visitors is not the only incentive for the presence of the English language at mass. Many younger-generation members today, particularly those born in Australia, might be brought up 'Chinese' at home, but learn to 
adjust culturally to life outdoors, which in mainstream Anglo-Australian society is highly 'Western'. These children are bilingual and more often than not English is their language of choice. Parents in recent years have found themselves addressing their children in English despite spending hard-earned money sending them to Chinese-language classes. Many children, especially those who have reached adulthood, are beginning to find little relevance in the community, which operates around Chinese mass - that is, mass in a Chinese language.

For those children who do not speak any Chinese, who find little point in it or, by association, find it antiquated and not very 'cool', introducing English into the Chinese community has served a very pragmatic function. It appeals to the community's children, who are 'Aussie now', and it attracts and accommodates people from outside the community who for various reasons attend Chinese mass. Almost ironically, while their predecessors 40 years ago found joy in introducing Chinese into what was once a Latin ceremony, many now find it necessary to incorporate some English in the Chinese mass community. There has been for several years now an English children's mass and a catechism class held adjacent to the regular Mandarin services in the school hall at St Dominic's Church. There are also catechism classes in Mandarin, Cantonese and English at St Peter Julian's Church. At important events and during mass for the grown-ups and the community at large, in which there are non-Chinese celebrants presiding over the entire community, parts of the mass are sung in English and there is at least one English hymn, which is normally the Recessional (exit) hymn.

Such was the linguistic situation at the community's fiftieth anniversary celebration in 2004. To cater for migrant children for whom singing in English had more preferential and symbolic weight, there were additional English hymns taken from some local, but modern hymnals.

As Mass ends, Give Thanks (Music 7.5) is sung in English and repeated once through in Cantonese. This presents quite an interesting bilingual situation stemming from the aim of catering for non-Chinese people in the congregation and clergy by using a modern hymn in which everyone, from within and outside the community, can participate. This hymn is performed with the accompaniment of electric organ, amplified guitar, bass guitar and drums. With the influence of popular music, hymns in English signify the process of domesticating once again in the new home country by adopting the local language. Give Thanks as a 'pop hymn' complies fully with the Vatican's Comme le prévoit (CLP) of 1969, which instructs that liturgical language (more particularly the language of translation) 'should be that in common usage' - that is, language 'suited to the greater number of faithful who speak it in everyday use'. ${ }^{16}$ I believe that this composition achieves in full what Eddie Ho's hymn accomplishes in making the music meaningful to people of Chinese and English-language backgrounds. In the case of such bilingual hymn singing, the use of English is more a need than 
a cultural or aesthetic choice in light of the as yet uncertain survival of native Chinese tongues in Sydney.

\section{Music 7.5 Give Thanks}

509

GIVE THANKS
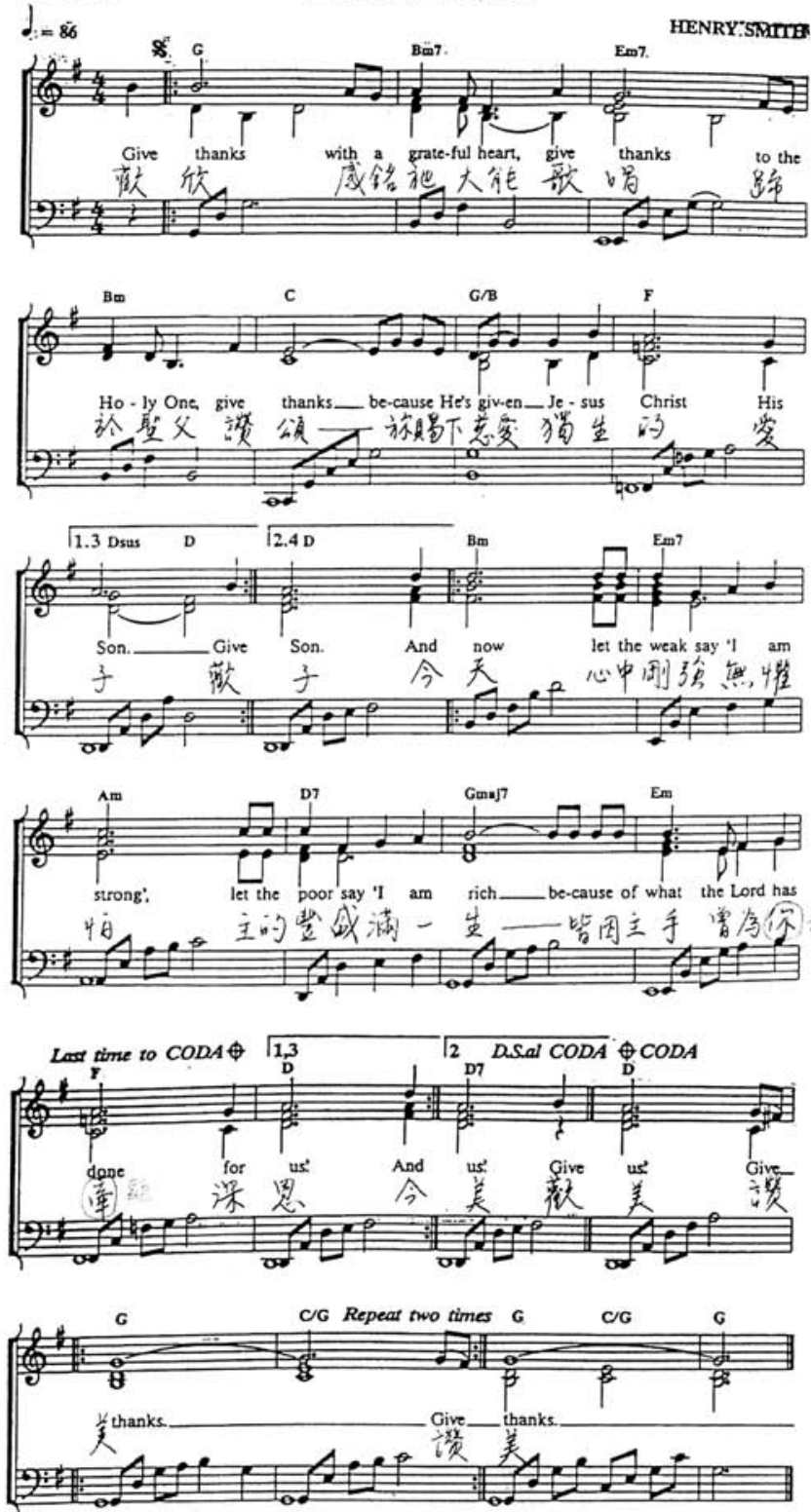


\section{Singing inter-culture}

The music of the ACCC presents an interesting case study of a 'hybrid cultural form(s)' (Ang 2001:35) conceived out of a productive, creative syncretism for the consumption and enjoyment of the congregation. We can see in the community's music what Ang (2001) calls a creative tension between past and present - that is, between 'where you're from' and 'where you're at', or 'what we might become', as Stuart Hall (1996:4) writes.

Catholic Chinese music in Sydney appears to reflect and even emulate the phases of musical development in the Western Church. This is particularly the case in some of the older repertoire introduced to Catholic Chinese communities before migration to Australia. Today, Catholic Chinese music is still affected by changes in the modern Church since Vatican II. ${ }^{17}$ What have directly affected and influenced the music that is still performed by Sydney's Chinese Catholics, however, are unaccompanied plainchant, accompanied plainchant and the 'traditional' hymns of the past with the accompaniment of the electric (church) organ. In recent decades, modern compositions, too, have conditioned the music at Chinese mass. The audiovisual examples above show hymns that are Western in nature and some that are more Chinese in orientation. Popular song genres such as the rock ballad have even been used as a model for hymns. Today, the electric organ and Western band instruments are used to accompany 'traditional' and 'modern' hymns, which are sung entirely in Mandarin, Cantonese, English or in a bilingual English/Cantonese alternating verse setting.

Unique to the community today is the composition of new Chinese hymns in Western style, the generational push for English and the trilingual presentation of the mass in Mandarin, Cantonese and English. This presents a case not so much of biculturality - that in-between space in which the individual is lost in the cultural translation from one side to the other of 'where you're from' and 'where you're at' - as one of hybridity, which Ang (2001:34-5) describes as that multi-perspective productivity filling the space of in-between-ness with 'new forms of culture at the collision of the two': in this case, the Australian and the Chinese, if we view it as such.

In the 'collision' of cultures, the penetration of English is inevitable and its influence continues to grow. While Chinese migrants worked hard to preserve the native tongue at home and at church in promoting their Chinese-ness as different to other local Catholics, they also sought to adapt to local customs through the English language instead of borrowing from established and internationally recognisable traits of 'Australian-ness'. In the Chinese community, English is regularly used in certain parts of the mass liturgy. It is also heard in the singing of hymns from modern Australian hymnals. There is an English version of the ACCC web site and non-Chinese and Chinese priests of the community have a fine command of English. Allowing for the use of English in 
the Chinese community in such a way helps the community gain a profile in mainstream society, because visitors are able to relate to what is happening through language and see how the community is different, but also the same in many respects. Allowing English to be used in the community serves the double purpose of accommodating Catholic Chinese children and their descendants, who are finding the community less and less appealing.

From the case studies and community history presented above, we can see an interesting dialogue of inter-culturalism created out of the examination of what makes up the 'other' from the viewpoint of Catholic Chinese. This community seems to have borrowed and appropriated into their own culture certain elements of a religion and culture that they consider foreign but important enough for there to be a need for change by inculturation or adaptation-before and after immigration to Sydney. For the purposes of this chapter, these elements are: Western chords and harmonies and the English language. I propose that, as the first inter-cultural step in music, appropriation in the community began with the introduction of the musical genre of the Western hymn.

Today, we can see all influential elements of the past and present woven into a new convention of music making, which has been achieved by Chinese Catholic community members observing the performance practice of mainstream (English-speaking) Catholicism and comparing it with what they have brought with them from abroad. Overall, there seems to be a conscious retention of older traditions in the growth of a new, modern sound - a new 'modern tradition' perhaps, in which, within the one community, we can observe many layers of ecclesiastical song that have evolved out of certain significant undercurrents that have shaped the community since its establishment in Sydney. These layers of music have the dual purpose - depending on genre or language - of asserting the community's difference from the mainstream or its ability to assimilate.

\section{Conclusion: singing salvation}

Living as Chinese, Catholic and Australian in suburban Sydney, members of the ACCC perform music that fulfils essential social, emotional and spiritual functions. From scholarly studies conducted on collective singing in various contexts, there is little doubt of the power that exists in singing in a group, especially in a religious context. The study presented above confirms that this is most certainly the case in the communal migrant situation of Catholic Chinese congregations in Sydney, where ecclesiastical singing is a by-product and a useful tool for religious and cultural expression through which we can observe and understand what these people as a community have accomplished since immigration. In this particular musical culture, we see reinvention, revitalisation and preservation in an eclectic whole towards the sustenance of a faith with the constant negotiation of a new identity through language use in ritual and song as Catholics who are Chinese, and as Chinese who are Australian. 
The preservation of old forms of singing and worship with the addition of new hymns and compositions in Mandarin, Cantonese and English with an inclination towards popular styles of music show that Catholic Chinese in Sydney have arrived at a functional, hybridised compromise in keeping as much of what they can of their homeland culture while reworking and even domesticating it to the new local landscape. Perhaps the community's current protean state is best summarised in the succinct but precise observation made by Edith Lo about the time of the CCPC choir's anniversary. In her own words, it is all about 'putting culture together with faith in order to bring the Chinese people together, and the young people too' (Interview with Edith Lo, 2000). Members are able to realise in music their culture and their religion. Clearly, the future of the community is very much in the hands of the younger generation, who can choose to sustain and nurture the socio-religious faith of their forefathers or find less and less significance in associating with members of the community. By making adaptive changes in ecclesiastical song for worship, Catholic Chinese in Sydney are with each mass and service singing for their salvation in the eternal kingdom and, more pragmatically or perhaps even metaphorically, for the survival of their community on the physical plane in the Chinese diaspora.

\section{Acknowledgments}

I am indebted to the following: Dr Stephen Wild (thesis supervisor), Dr Mandy Scott (advisor), Hong Shin Chan, Paul Maclay and, most importantly, Dr Amy Chan and Alistair Noble, to whom this chapter in its current form owes its existence.

My deepest thanks extend to members of the Australian Catholic Chinese Community: Father Bonaventure Tung (OFM), Father Pascal Chang (OFM), Father Paul McGee (SSC), Joannes Chan (WSCCC President), Joseph Chow (CCPC President), Ken Lay (former WSCCC President), Ivan Ho (CCPC Choir President), Eddie and Annie Ho, Zita Ho, Adelino and Iana Chungyue, Joseph Lee, Edith and Ken Lo, Catholic Chinese Pastoral Centre Choir and Western Sydney Catholic Chinese Community Choir.

\section{Bibliography}

Anderson, Benedict 1991, Imagined communities: Reflections on the origin and spread of nationalism, Verso, London and New York.

Ang, Ien 2001, On Not Speaking Chinese: Living between Asia and the West, Routledge, London and New York.

Averill, Gage 1994, “Mezanmi, Kouman nou ye? My friends, how are you?": musical construction of the Haitian transnation', Diaspora, vol. 3, no. 3, pp. 253-71. 
Beall, Stephen M. 1996, 'Translation and inculturation in the Catholic Church', Adoremus Bulletin: Society for the Renewal of Sacred Liturgy, vol. 2, no. 6, viewed 8 September 2005, <http://www.adoremus.org/1096-Beall.html>

Catholic College Students Association 1983, Q ng g zhàn zh róng [Light Songs in Worship of God's Glory], Second edition, Catholic College Students Association, Taiwan.

Chun, Allen 1996, 'Fuck Chineseness' In Boundary 2 23(2): 111-138.

Cowles, Roy T. 1965, The Cantonese Speaker's Dictionary, University Press, Hong Kong.

Dewey, John 1916, Democracy and Education, Macmillan, New York.

Frith, Simon 1996, 'Music and identity', in S. Hall and P. D Gay (eds), Questions of Cultural Identity, Sage, London, pp. 108-27.

Hall, Stuart 1996, 'Introduction: who needs "identity"?', in S. Hall and P. D. Gay (eds), Questions of Cultural Identity, Sage, London, pp. 1-17.

Heilbron, J. L. 1998, 'In diaspora', in Wang Ling-chi and Wang Gungwu (eds), The Chinese Diaspora: Selected essays, Times Academic Press, Singapore.

Hong Kong Catholic Truth Society 1983, X n sòng: xin y u g ji [Songs of Praise from the Heart: Congregational song collection], Second edition, Hong Kong Catholic Truth Society, Hong Kong.

Hong Kong Catholic Truth Society 1985, Sòng $n$ : sin y u g jì [Songs of Praise: Congregational song collection], Hong Kong Catholic Truth Society, Hong Kong.

Hosokawa, Shuhei 1998, 'Singing in a cultural enclave: karaoke in a Japanese Brazilian community', in Toru Mitsui and Shuhei Hosokawa (eds), Karaoke Around the World: Global technology, local singing, Routledge, London and New York, pp. 139-65.

Kelen, Christopher 2003, 'Anthems of Australia: singing complicity', National Identities, vol. 5, no. 2, pp. 161-77.

Kwan, Choi Wah et al. 2000, English-Cantonese Dictionary: Cantonese in Yale romanization, The Chinese University Press, Hong Kong.

Lau, Frederick 2005, 'Entertaining "Chineseness": Chinese singing clubs in contemporary Bangkok', Visual Anthropology, vol. 18, pp. 143-66.

Lum, Casey Man Kong 1996, In Search of a Voice: Karaoke and the construction of identity in Chinese America, Lawrence Erlbaum Associates, New Jersey.

Martin, Michael 1998, 'Pange lingua', Theasaurus Precum Latinarum, viewed 19 May 2006, <http://www.preces-latinae.org/thesaurus/Hymni/Pange.html> 
Michael Forrester, F. 2004, 'Lions, a cardinal and two dancing dragons: valid inculturation or monkey business?', Los Angeles Lay Catholic Mission, March, viewed14 November 2005, <http://www.losangelesmission.com/ed/articles/2004/0403ff.htm>

Minamiki, G. 1985, The Chinese Rites Controversy: From its beginning to modern times, Loyola University Press, Chicago.

Mungello, D. E. et al. 1994, The Chinese Rites Controversy: Its history and meaning, Steyler Verlag Nettetal, Germany.

Nettl, Bruno 1983, The Study of Ethnomusicology: Twenty-nine issues and concepts, University of Illinois Press, Urbana-Champagne, Ill.

O'Brien, Thomas (ed.), 1982, 'Comme le prévoit', Documents on the Liturgy, 1963-1979, The Liturgical Press, Collegeville, pp. 284-91.

Ogawa, Hiroshi 1993, Karaoke in Japan: a sociological overview, Paper presented at the eighth International Conference on Popular Music Studies, Stockton, California.

Radano, Ronald M. and Bohlman, Philip V. (eds) 2000, Music and the Racial Imagination, University of Chicago Press, Chicago.

Shorter, Aylward 1988, Toward a Theology of Inculturation, Orbis Books, Maryknoll, NY.

Siu, Helen 1993, 'Cultural identity and politics of difference in South China', Daedalus, vol. 122, no. 2, pp. 19-43.

Slobin, Mark 1993, Subcultural Sounds: Micromusics of the West, University Press of New England, Hanover, New Hampshire.

Slobin, Mark 1994, 'Music in diaspora: the view from Euro-America', Diaspora, vol. 3, no. 3, pp. 243-51.

Small, Christopher 1998, Musicking: The meanings of performing and listening, University Press of New England, Hanover, NH.

Stokes, Martin 1994, 'Introduction: ethnicity, identity, and music', in Martin Stokes (ed.), Ethnicity, Identities, and Music, Berg Publishers, Oxford, pp. 1-28.

Tan Chee-beng 1988, 'Structure and change: cultural identity of the Baba of Melaka', Bijdragen tot de Taal-, Land-en Volkenkunde, vol. 144, nos 2-3, pp. 297-314.

The Catholic Weekly 2004, 'Our Lady: a tribute in art', The Catholic Weekly. Special Souvenir, vol. 2 [brochure].

Tung, Bonaventure 2006, Letter addressed to Nicholas Ng, May. 


\title{
Discography
}

\author{
Aì G Rén Sh ng Lù [Music Lovers' Life Journey], 2000, Asiana Centre Association, \\ Ashfield, Sydney.
}

\section{Endnotes}

1 A Roman Catholic feast that falls traditionally on 2 November in the Gregorian calendar, after All Saints' on 1 November.

2 An indigenous Chinese festival also known as the Ching Ming Festival (in Hong Kong) during which the graves of the departed are swept; traditionally held about 5 April (near Easter). Prayers are made with libations and food is offered.

3 The Veneration of Ancestors (a Confucian rite) is a civil ceremony in remembrance of Confucius and family ancestors. Jesuit missionaries condoned this ritual as they wove indigenous Chinese concepts into the Roman Catholic faith in China through the methodology of inculturation. This resulted in the Edict of Toleration in 1693, which declared Christianity licit. Pope Clement XI, however, condemned the 'Chinese rites' in 1715 and ordered them to be suppressed. The ban was not lifted until the decree of 1939 published during the pontificate of Pope Pius XII, which authorised the Chinese to take part in certain Confucian rites including the 'Chinese rites' of ancestral veneration. Later, the reforms of Vatican II further encouraged the admission of native ceremonies (such as the Australian Aboriginal smoking ceremony) into church liturgy. For more information, see Minamiki (1985); Mungello et al. (1994); and Michael Forrester (2004).

${ }^{4}$ Notes taken during a special celebratory mass to mark the fiftieth anniversary of the ACCC and the one hundred and fiftieth anniversary of the Promulgation of the Dogma of the Immaculate Conception. The occasion saw the blessing of the statue of Our Lady of the Immaculate Conception and the launch of the Catholic China Mission Service Project by Australian Franciscan Provincial Father Stephen Bliss. 5 A movement by overseas Catholic communities, in particular communities of Chinese Catholics and sympathisers, to raise awareness of and support the Roman Catholic Church in China, which since the Cultural Revolution (1966-76) has been oppressed by the Chinese Government.

6 Here, it should be noted that the ACCC is one of two main organisations of Chinese Catholics within the Archdiocese of Sydney. The other is the Chinese Catholic Community Incorporated (CCC). Due to limited time and resources, the scope of my study includes only the first organisation.

7 The topic of Latin hymnody is worthy of a discussion on its own.

8 The edict of Vatican II inspired the methodology of 'inculturation' in twentieth-century church reform and allowed the cultural cross-fades evident in many 'ethnic' communities worldwide. By definition, inculturation is 'the creative and dynamic relationship between the Christian message and a culture or cultures' (Shorter 1988:11) and it was implemented as early as the 1600s by Jesuit missionaries in China. Inculturation encourages local forms of Christianity to emerge out of the belief that the elements of the gospel are hidden in every culture and that it is the duty of theologians, pastors and liturgists to bring this hidden light into full view (Beall 1996).

${ }^{9}$ Strong examples of inculturation can be found in the Chinese New Year mass of 2004 at the Cathedral of Our Lady of Angels, Los Angeles. During the procession of clergy, there were two sets of lion dancers and two dancing dragons. There was also a Chinese lantern dance and ribbon dance performed by women during the offertory. Although said mostly in the Chinese vernacular, mass was conducted in the Roman Rite with some variations allowed by the presiding Cardinal Roger Mahony with principal celebrant Bishop Ignatius Wang (Michael Forrester 2004).

10 Mass was first celebrated in the crypt of St Mary's Cathedral but was later moved to the Asiana Centre by Father Chang (<http://www.chinese.sydney.catholic.org.au/E_Aca.htm >, viewed 7 May 2005).

11 According to the ACCC web site, the community caters for the 'religious, social, educational and welfare activities for all people of Catholic Chinese background'

(<http://www.chinese.sydney.catholic.org.au/E_Aca.htm>, viewed 7 May 2005).

12 The numerical representation of notes used as an alternative to Western staff notation.

13 These hymnals are used outside Sydney. On a recent fieldtrip to visit the Chinese Catholic Association of London (August 2005), I noticed the same Pew Edition hymnals as those used in the ACA/CCPC. 
14 Depending on the authoritative source consulted, there are six, seven or nine Cantonese tones. This study is based on the viewpoint of my informants as well as The Cantonese Speaker's Dictionary (Cowles 1965) and the English-Cantonese Dictionary (Kwan et al. 2000).

15 A closer study of Roman Catholic liturgical text in Chinese can be found in my doctoral thesis, Celestial roots: the music of Sydney's Chinese, 1954-2004 (pending).

16 At the CCPC choir's twentieth anniversary dinner in July 2005, I heard a Cantonese pop song performed with its lyrics edited to take on a slightly more liturgical meaning. This is rich in intercultural meaning and speaks of the dynamics between the expatriate Hong Kong community and their country of origin. This is, however, a case study for another paper.

17 This is a subject with further avenues of research, as, to date, no comprehensive study on this topic exists, particularly in Australia. 